\title{
Canada Goose Sanctuary Project
}

Fred G. Bard

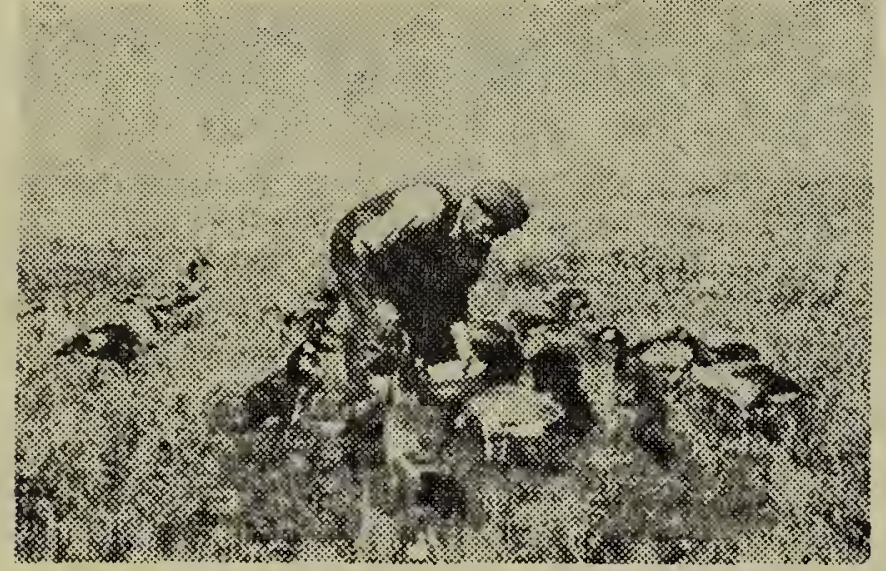

-Photo by Bard.

TNHE REGINA BRANCH of the Fish and Game League and the Game Branch, Dept. of Natural Resources are working together to reestablish the Canada Goose on Last Mountain Lake. This project is under the supervision of Ralph "Hiawatha" Steuck, of Abernethy. Ralph is keenly interested in the future status of the Canada Goose. For several years he has raised these birds successfully on his "Kerry Farm" in Abernethy.

Thrcugh the co-operation of sportsmen, money has been collected to fence a five acre pen on an arm of Last Mountain Lake. Eggs, from established preserves, were placed under sitting hens. In due course young goslings arrived, accompanied by the faithful mother hen. The families were taken to the farm of Arthur Perry, of Govan, who generously cared for the young birds. It meant considerable work to feed, protect and gather these thirty odd birds each night.

W'ien Mr. E. L. Paynter, the Game Commissicner, Ralph Steuck and I visited the pens in August, the birds were in fine condition and growing rapidly - a real tribute to their keeper.

The Game Branch has acquired land inside the Bird Sanctuary at the north end of Last Mountain Lake. This area was seeded down to wheat and proauced a fine crop. During the congregating of the ducks, this fall, this field was alive with birds.

It is difficult to effectively assist waterfowl in an area without causing damage to farmers' crops in the vicinity. The Game Branch has succeeded in improving this waterfowl resting area and to some extent assisted in controlling the feeding ducks from damaging the crops.

\section{Maggie and Jiggs, the Photographer}

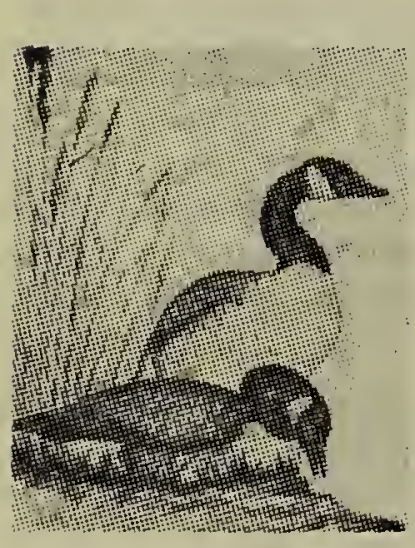

Buck Stueck, Abernethy

A $\mathrm{T}$ the present time there are ten A Canada Geese, seven English Call Ducks, three wild Mallards and a pair of good looking Muskrats staying at my little sanctuary.

It is inieresting to watch them as they all mingle together at different times of the day. Occasionally a muskrat gets his tail pinched by Jiggs, the gander who is all-over manager of the pond, Maggie stands by and generally approves of his bossy behavior.



As the cold winds of winter began to

freeze over the pond and leave but one hole in the ice for all parties to swim in, it was quite noticeable that old arguments were over and even the two muskrats enjoyed the last open spot. They would sit on the edge of the ice and eat grain while the ducks and geese swam about.

One day I decided to set the movie camera up on a tripod to get a picture of the two muskrats. After everything was in order, and a long string from the camera to the house window was installed, I went in to have dinner. Immediately after dinner I went to the window to see if the muskrats were feeding in the proper position so that I could pull the string and get their pictures. To my surprise, Jiggs the goose was holding the string and jerking away. The camera was run down and he had already taken the picture. 